\title{
Evaluation of Reducing Feminism on Poverty Program in East Java
}

\author{
Hartati Kartikaningsih ${ }^{1 *}$, Khotibul Umam Al Awwaly ${ }^{2}$, Rachman Hartono ${ }^{3}$ \\ ${ }^{1}$ Department of MSP, Faculty of Fisheries and Marine Science, Brawijaya University Malang, 65145, \\ Indonesia \\ ${ }^{2}$ Faculty of Animal Husbandry, Brawijaya University Malang, 65145, Indonesia \\ ${ }^{3}$ Department of Socio Economics, Faculty of Agriculture, Brawijaya University Malang, 65145, \\ Indonesia \\ Received: 20 January 2020; Revised: 11 May 2020; Accepted: 23 July 2020
}

\begin{abstract}
Controlling is always needed in every public policies and programs, through both of monitoring and evaluation on the process, the conformability between its process and the purposes, outputs, and impacts. The aim of this research was to monitor and to evaluate the overcoming feminism on poverty program during 2018 in some cities in East Java Province, used descriptive-qualitative method. The data was collected by visiting and surveying the sites. Research locations were determined by proportional sampling method considering kinds of business process run by targeted households in each village. Two hundred and three households from twenty villages and seven cities were monitored and evaluated, which were represented about ten percent of the population. The research showed that the success rate of the program was $96.50 \%$. as measured by the accuracy of the target (100\%), the accuracy of receiving the amount of aid and its use (100\%) as well as aspects of the benefit of the aid (89.49\%). From the aid provided, $87.19 \%$ led to self-motivation in doing business, increasing in income, capital, and assets were $84.24 \%, 84.24 \%$, $87.68 \%$ as well as environmental supporting was $88.67 \%$. There was no similar activity from the regional government in term of equal distribution of the aid and program sustainability. The family supporting from the households ensure the success of this program.
\end{abstract}

Keywords: evaluation; monitoring; feminization; output; impact

\section{How to Cite:}

Kartikaningsih, H., Al Awwaly, K. U., \& Hartono, R. (2020). Evaluation of Reducing Feminism on Poverty Program in East Java. Habitat, 31(2), 102-108. https://doi.org/10.21776/ub.habitat.2020.031.2.12

\section{Introduction}

Poverty is a multidimensional concept and phenomenon (Suharto, 2009). Poverty is influenced by various interrelated factors, including: level of income, health, education, access to goods and services, location, geography, gender, and environmental conditions. Poor female household heads are one of the dimensions of poverty in East Java. From East Java PDPT data, there are thousands of poor female household heads. Reducing feminism on poverty is a program carried out by the East Java government since 2014-2019. This program was carried out to help alleviate poverty, especially for female heads of households in order to be able to improve their quality of life by providing financial assistance to

${ }^{*}$ Correspondence Author.

E-mail : hartatikartikaningsih@gmail.com

Telp :+62-821-430-99909, Fax 0341556837 be used as business capital. So far the program has been carried out in rural areas in East Java, except for the implementation on 2018.

As the implementation of public policy, the reducing feminism on poverty program in urban poverty in East Java in 2018 required control included both monitoring and evaluation. These monitoring and evaluation was carried out in order to capture how the program was implemented, to assess whether the implementation met the program's objectives, and to identify the outputs then compare them to the success indicators that have been set, such as: accuracy of target, number, and utilization to measure the success of the program. Moreover, the findings will be used to enrich recommendations for improving the quality of programs, especially in terms of impact and sustainability programs for Women Household Heads (KRTP). KRTP is a woman who for some reason (divorced, husband died, abandoned husband, and husband with disability/disability/ 
chronic illness) that causes women to carry out social and economic functions as heads of households.

The reduction of feminization on poverty (PFK) is a program designed specifically and inclusively to optimize and make effective poverty reduction programs aimed at poor households with female heads of household (KRTP) which encourage women heads of household to be independent.

The independence of women is inseparable from the spending of time in work, capital and environmental support. The time spent by women to earn income has been widely studied, especially in relation to the risk of HIV/AID (Wodon \& Blackden, 2006); (Krishnan, Dunbar, Minnis, Medlin, Gerdts, \& Padian, 2008); (Kim \& Watts, 2005) as well as related to the independence of women workers as laborers (Yulida \& Edwina, 2014); (Wawansyah, Gumilar, \& Taofiqurohman, 2012); (Nugraheni, Marhaeni, \& Sucihatiningsih, 2012) The independence of women generally comes from training (Laksana, Sholih, \& Naim, 2017); (Minarni, Utami, \& Prihatiningsih, 2017) provision of capital (Rizal, Setianingsih, \& Chandra, 2016) and environmental influences (Kirana, Kusrini, \& Purwanto, 2018) however researches on monitoring and evaluating the success of a program were still limited. This research was aimed at monitoring and evaluating the 2018 PFK Jalin Matra program in urban areas in East Java. The results of monitoring and evaluation were expected to provide useful information for decision makers to obtain objective data and information about the implementation of programs that have been carried out, to know the impacts, potentials, strengths and weaknesses in order to make improvements and determine policies to be taken based on evaluations have been done.

\section{Research Methods}

This study employed descriptive qualitative methods (Nawawi \& Martini, 1996) to describe facts, circumstances or symptoms that appear in the implementation and results of program activities. Data were collected using field research methods (field research) and surveys.

Sources of data used in monitoring and evaluation were both primary and secondary data. Primary data were obtained by conducting indepth interviews and direct discussions with key informants related to the PFK program, such as: the managers of the PFK program at the provincial level (provincial PMD offices and companion colleges), the managers at the city level (urban OPD and City Facilitators), the managers at the village level (local government and head-village's secretary), society group's administrators, and KRTP beneficiaries of the 2018 PFK program. Data was collected through questionnaires, interviews, and discussions.

Secondary data were obtained from some written documents in an effort to explore data related to problems and activity objectives and to give strong justification for the results of monitoring and evaluation implementation, as well as for analysis purposes. These documents included: (a) The general guidebook for Jalin Matra PFK for urban locations in 2018; (b) The Operational Technical Guidebook; (c) The Assistance Technical Guidebook; (d) The PFK program assistance activity report year 2018; and (e) annual reports of program implementation from each targeted villages.

Research location was determined by the proportional sampling method by considering: (1) Target list of PFK Program for urban village locations in 2018; (2) Grant assistance mechanism for community groups of KRTP, and (3) the villages where targeted households live and have various types of business.

Determination of sampling from KRTP used the snowball method which was covering at least $10 \%$ of the total target KRTP. In total, this research employed 203 KRTP from 20 villages of 7 cities in East Java, such as Malang, Pasuruan, Probolinggo, Madiun, Blitar, Mojokerto and Kediri.

\section{Results and Discussion}

\subsection{Program Evaluation}

The Jalin Matra PFK Program for Urban Areas in 2018 was implemented upon the General Guidelines Towards Independent and Prosperous East Java Province for Urban Areas in 2018, which were stipulated in the Regulation of the Governor of East Java Number 5 of 2018 (Prisristiyanti, 2012).

Implementation of the Jalin Matra PFK program as described in the General Guidelines for urban locations includes following activities: (1) socialization; (2) consultation; (3) clarification and identification of proposed KRTP needs; (4) submission of aid disbursement; (5) preparation meetings and assistance for implementation; (6) procurement of inputs needed; (7) delivery of relief items to KRTP; (8) technical guidance; (9) 
preparation of accountability report, 10) Program management and continuity. The results of monitoring and evaluation showed that the implementation of the Jalin Matra PFK Program has been carried out accordingly to the general guidelines.

The results of evaluation of the Jalin Matra

PFK Program for Urban in 2018 indicated that:

(1) not all cities have allocated specific budgets to solve RTS' that were not included as program targets through sharing or independent funds, nor have shown their commitment to conduct a sustainability/ conservation program;

(2) the Jalin Matra PFK Program in urban locations has been socialized and made submissions through leveraging activities and transfer of RTS assistance in 2014, and only realized in 2018 ;

(3) operational fund for of society groups was allocated only $5 \%$ of the KRTP fund, which was deemed insufficient according to program's implementation assistance book, guidance for technical and monitoring as post-program assistance as well;

(4) the disbursement of assistance grant for society groups was tend to be late, usually at the end of the year, made the administrators of the society groups, as the recipients, worked harder in preparing things needed to hold the program, thus often caused them failed to carry out postprogram assistance, including technical guidance and assisting business development, due to the limited time;

(5) according to the grant mechanism, society groups are given flexibility in both number of activities and budgets, so they could be more educated as an economic group, because they were fully and activelly involved in planning, implementation, financial management, spending, and realization of assistance;

(6) technically, the procedures allow the society groups' management to be involved in procurement processes, so that the KRTP could choose the type of goods according to the habits and specifications required by the KRTP. With this involvement, the independency principle of KRTP was truly realized, where KRTP could have shopping experience (especially when they hold new businesses) so that they could do procurement by their own-self in the future;
(7) in terms of human resources, society groups administrators were already good at facilitating and assisting KRTP grants, in which the administrators could meet the social and economic needs of society groups members' KRTP;

(8) there were no preservation activities conducted during 2018.

Program evaluation closely related the compliance of civil servants, especially the local (village) government staffs, as the main actors during the program implementation. (Peraturan Gubernur Jawa Timur Nomor 5 Tahun 2018, 2018) showed that the internal control system and compliance, organizational ethical culture, and organizational commitment have a negative effect on fraud in the government sector. Being a civil servant is still the prima donna of the younger generation so that the program implementation has been running as it should be. In addition, this activity does not require employees to stay in the office, so that employee compliance and discipline greatly affect the success of the program (Yoesana, 2013).

\subsection{The indicators for a success evaluation}

Indicators of success of the Jalin Matra PFK Program were derived from the General Guidelines of Jalin Matra for Urban Areas in 2018 which were reviewed and measured based on the accuracy of program's target and its benefit for target households (RTS), the balance between the number of received with utilized fund.

The accuracy of program's target was measured used the criteria set out in the general guidelines, those were: (1) the number of households whose welfare status were only ten percent or lower (Decile 1), based on Integrated Database (PPFM) 2015 through a deliberation and verification by residents; (2) the number of households led by women, due to divorce, sick/disable/died husbands, or being neglected; (3) the number of female-head of households who have members aged 15 - 65 years and/or being alone on productive age; (4) villages with at least 20 KRTP households would be prioritized.

Analysis on those accuracy aspects was assessed used four indicators, included: (1) the number of fund received by all of Jalin Matra PFK members according to the provisions; (2) the percentage of funding used by KRTP, which was assessed from the accuracy of the grant spending for main business, for supporting businesses, and for basic needs; (3) the equality between the type of business with the proposed KRTP needs; (4) the 
equality between the spending in details with the budget plan written on the KRTP proposal.

Indicators of the program benefit were analyzed from economic, psychological, and social Aspects. The findings showed that the success rate of the Jalin Matra PFK program for urban areas in 2018 was $96.50 \%$ in average. The biggest contribution was on the targeting accuracy and the equality between the amount received and spent during the program, with a perfect score of $100 \%$. While, the benefits of the funding were assessed as $89.49 \%$ achieved. The detailed results were shown in Table 1.

Table 1. The results of Evaluation on Success Indicators of the Program

\begin{tabular}{|c|c|c|c|}
\hline \multirow{2}{*}{ No. } & \multirow{2}{*}{$\begin{array}{l}\text { Indicators } \\
\text { evaluated }\end{array}$} & \multicolumn{2}{|c|}{ Results (in \%) } \\
\hline & & Appropriate & $\begin{array}{c}\text { Not } \\
\text { appropriate }\end{array}$ \\
\hline 1 & $\begin{array}{l}\text { The accuracy } \\
\text { of target }\end{array}$ & 100,00 & 0,00 \\
\hline 2 & $\begin{array}{l}\text { The equality } \\
\text { between } \\
\text { amount } \\
\text { received and } \\
\text { spent }\end{array}$ & 100,00 & $\mathbf{0 , 0 0}$ \\
\hline 3 & $\begin{array}{l}\text { The benefits } \\
\text { of program }\end{array}$ & 89,49 & 10,51 \\
\hline & Average & 96,50 & 3,50 \\
\hline
\end{tabular}

Respondents who were identified did not get the benefit of the funding reasoned that the fund was mostly spent for their daily needs. The success of entrepreneurship for female household heads is largely based on the support of their family and the surrounding environment. Assistance for successful RTS was also due to assistance only as additional capital. They have done business before. (Lestari, 2013) mentioned the perception of risk in making entrepreneurial decisions. The driving factor in a year for RTS to become entrepreneurial was the emergence of concerns about returning the funds that had been given if they failed in entrepreneurship. The results of the study (Carter, Shaw, Lam, \& Wilson, 2007) also confirm the success in entrepreneurship for women because they have their own business.

\subsection{Output analysis}

According to (Kaluge,2000), output defines as the result of the activity or service of a program which is measured using the volume measure. The Jalin Matra PFK Program is a special financial assistance program for specific allocation, and has to be spent for buying any business facilities as well as basic needs.

The outputs measured in the 2018 monitoring and evaluation of the PFK program included: (1) the value of business capital obtained from the assistance fund; (2) the progress and development of KRTP's business achieved after receiving the funding; and (3) the type of business run by the RTS using the assistance fund.

The results showed that the main business capital allocated by KRTP was Rp. 2,254,926.11,in average. If this value was multiplied by the total number of targeted KRTP in 2018, which was 1641 KRTPs, the amount of venture capital that has been realized by KRTP from the implementation of this program was $\mathrm{Rp}$. 3,700,333,743.84.

The output of the Jalin Matra PFK Program based on the members' main business development. It was found that increasing on capital and assets were the biggest development gained from this program, as much as $51.67 \%$. Detailed results was depicted in Table 2.

Tabel 2. Output Based on Type of RTS Business Progress

\begin{tabular}{clr}
\hline No. & Type of progress & \% \\
\hline 1. & Increasing capital and assets & 52.89 \\
\hline 2. & New business unit & 9.12 \\
\hline 3. & Business diversification & 4.86 \\
\hline 4. & New experience & 1.82 \\
\hline 5. & Increasing turnover and incomes & 27.05 \\
\hline \multirow{2}{*}{ 6. } & $\begin{array}{l}\text { Provide new job opportunities } \\
\text { for family members }\end{array}$ & 4.26 \\
\hline \multicolumn{2}{c}{ Total } & $\mathbf{1 0 0 . 0 0}$ \\
\hline
\end{tabular}

Tabel 3. Output Based on Main Business Type

\begin{tabular}{|c|c|c|}
\hline No. & Type of business & $\%$ \\
\hline \multirow[b]{2}{*}{1.} & Trading: & \multirow[b]{2}{*}{50,74} \\
\hline & $\begin{array}{l}\text { Example: groceries, retailer mobile } \\
\text { traders, hawkers, rujak, rice stalls, } \\
\text { coffee shops, kiosks }\end{array}$ & \\
\hline \multirow[b]{2}{*}{2.} & Service: & \multirow[b]{2}{*}{11,33} \\
\hline & $\begin{array}{l}\begin{array}{l}\text { Example: massage, laundry, hircut } \\
\text { (barber) }\end{array} \\
\end{array}$ & \\
\hline \multirow{2}{*}{3.} & Livestock: & \multirow{2}{*}{3,45} \\
\hline & Example: poultry, goat & \\
\hline \multirow[t]{2}{*}{4.} & Handcraft & \multirow{2}{*}{2,46} \\
\hline & Example: dolls, wall decoration & \\
\hline \multirow[t]{3}{*}{5} & MSME & \multirow{2}{*}{32,02} \\
\hline & Example: cookies, snacks & \\
\hline & Total & 100,00 \\
\hline
\end{tabular}

Detailed data could be seen in Table 3 . The results also indicated that the Jalin Matra PFK Program generated various business types run by 
KRTPs. The output of business type that gave the largest contribution was trading (50.74\%) which was including groceries, retailers, mobile traders, hawkers, rujak (javanese fruit salad), rice stalls, coffee shops, kiosks, etc. MSMEs was the second greatest business type that built by the KRTPs through this program, that was $32.02 \%$. Their products included cake, cracker, snack and others business.

Analysis of the impact of the Jalin Matra PFK program consisted of economic, social, and psychological aspects. According to the monitoring and evaluation analysis, the PFK program had significant impact on developing RTS' business, valued as $73.62 \%$, in average. The highest impact was contributed by economic aspects $(87.60 \%)$. Further results was recapped in Table 4.

Table 4. Impact Analysis of the Program on the Business Development

\begin{tabular}{clcl}
\hline \multirow{2}{*}{ No. } & \multirow{2}{*}{ Aspect } & \multicolumn{2}{c}{ Results (in \%) } \\
\cline { 3 - 4 } & & Improved & Not improved \\
\hline 1. & Economy & 87,60 & 12,40 \\
\hline 2. & Social & 46,06 & 53,94 \\
\hline 3. & Psychology & 87,19 & 12,81 \\
\hline & Average & $\mathbf{7 3 , 6 2}$ & $\mathbf{2 6 , 3 8}$ \\
\hline
\end{tabular}

The economic impact was measured by business operational variables (which used variables of business development and increasing in working capital) and increasing income (as seen in Table 5). The results of data analysis showed that the Jalin Matra PFK Program affected the economic development by $87.55 \%$ in average. This value was derived from the contribution of business operational (90.97\%) and average income (84.24\%).

Table 5. Economic Impacts

\begin{tabular}{cccc}
\hline & \multirow{2}{*}{$\begin{array}{c}\text { Measurement } \\
\text { variables }\end{array}$} & \multicolumn{2}{c}{ Results (in \%) } \\
\cline { 3 - 4 } & & Improved & $\begin{array}{c}\text { Not } \\
\text { improved }\end{array}$ \\
\hline 1. & Operational & 85,84 & 14,16 \\
\hline a. & Business development & 90,97 & 9,03 \\
\hline b. & Capital & 98,52 & 1,48 \\
\hline c. & Assets & 87,68 & 12,32 \\
\hline 2. & Income (monthly) & 86,70 & 13,30 \\
\hline & Average & 84,24 & 15,76 \\
\hline
\end{tabular}

The average increasing in KRTP income was Rp. 794,384,- per month, which was greater than the average increasing of monthly revenue from monitored locations in 2018 that was only Rp. 581.133,-. Respondents' ability to do business has been internalized from their habits in raising livestock, trading and farming. Respondents who were not accustomed to work, tend to spend the fund they received for daily needs.

Analysis on the social impact of the PFK program measured by: increasing in social participation by RTS and environmental support for RTS businesses. In detail, the results of these social impact analyses described in Table 6.

Tabel 6. Social Impacts

\begin{tabular}{llcc}
\hline \multirow{2}{*}{ No. } & $\begin{array}{c}\text { Measurement } \\
\text { variables }\end{array}$ & \multicolumn{2}{c}{ Results (in \%) } \\
\cline { 3 - 4 } & \multicolumn{1}{c}{ Increased } & Stagnant \\
\hline 1. & $\begin{array}{l}\text { Participation of } \\
\text { RTS }\end{array}$ & 3,45 & 96,55 \\
\hline \multirow{2}{*}{2.} & $\begin{array}{l}\text { Environmental } \\
\text { support toward } \\
\text { RTS' business }\end{array}$ & 88,67 & 11,33 \\
\hline & Average & $\mathbf{4 6 , 0 6}$ & $\mathbf{5 3 , 9 4}$ \\
\hline
\end{tabular}

The results stated that the social impact which had the biggest effect on the KRTPs' businesses was environmental support aspect $(88.67 \%)$. This aspect has been one of the potential and strategic capital for KRTP to increase motivation in developing a business. The findings of this research also indicated that social environment has a positive impact on business behavior. Previous research of (Sudirman, 2016) also proved that motivation (to earn higher income) has a positive correlation to developing a business, while environmental motivation has less impact. For marginal areas, the ability to do entrepreneurship is strongly influenced by the social environment. This was confirmed by the educational background of respondents at which most of them did not graduate from school or only graduated from elementary school.

The psychological impact was assessed from the perception of KRTP on increasing selfmotivation in doing business. In a large psychology dictionary, perception is defined as a process of observing a person's environment by using his own senses so that he becomes aware of everything in his environment (Chaplin, 2008). Perception has a subjective character, because it depends on the abilities and circumstances of each individual, so that it will be interpreted differently by one individual to another.

The 2018 Jalin Matra PFK Jalin program has a psychological impact on increasing KRTP self-motivation, which was valued as $87.19 \%$. This motivation is expected to be the basic capital for KRTP to continue emerging productive economic businesses, socialize, and build a wider network. Other previous researches, (Klein \& 
Hodges, 2001), indicated the same condition. Moreover, increasing income and sympathy is proven to give positive psychological motivation that similar to family support in motivating students' activities (Fredricks \& Eccles, 2005).

\section{Conclusion}

According to results of this research, through the monitoring and evaluation process on the PFK program for urban areas in 2018, it could be concluded that:

(1) Program was implemented in accordance with the PFK program guidelines.

(2) The average success rate was $96.50 \%$ measured by three following indicators: the accuracy of targets (100\%), accuracy in the number of funding receiver $(100 \%)$, and the program benefit $(89.49 \%)$.

(3) The value of venture capital gain from this program was Rp. 2,254,926.11,- in average, from the increasing capital and turnover.

(4) The dominant business sector carried out by KRTP is trading.

(5) Economic impact of this program reached $87.60 \%$, which was indicated by the KRTPs' average income that was increasing by Rp. 794,384, - per month.

The results of this research will be imply both theoretically and practically. Theoretically, this research is expected to contribute in to the development of social science, especially in social poverty reduction. While the practical implications of this research are providing data and information to evaluate the implementation of this program. Moreover, the results also can be used as additional reference for stakeholders (especially the Government) in determining the direction of urban poverty reduction policies.

\section{References}

Suharto, E. (2009). Membangun Masyarakat Memberdayakan Rakyat, Kajian Strategis Pembangunan Kesejahteraan social dan Pekerjaan Sosial, Cetakan 3. Bandung : PT Rafika Aditama.

Wodon Q, Blackden CM,. (2006). Gender, time use, and poverty in sub-Saharan Africa. The World Bank working paper no 73 Washington; Jan 11.145 hal.

Krishnan S, Dunbar MS, Minnis AM, Medlin CA, Gerdts CE, Padian NS. (2008). Poverty, gender inequities, and women's risk of human immunodeficiency virus/AIDS.
Annals of the New York Academy of Sciences.;1:101-136.

Kim JC, Watts CH. (2005). Gaining a foothold: tackling poverty, gender inequality, and HIV in Africa. Bmj. 2005 Sep 29;331(7519) : 769-72.

Yulida R, Edwina S. (2014). Curahan waktu wanita dan kontribusinya terhadap pendapatan rumah tangga. Jurnal Parallela.1(2):143-50.

Wawansyah H, Gumilar I, Taofiqurohman A. (2012). Kontribusi ekonomi produktif wanita nelayan terhadap pendapatan keluarga nelayan. Jurnal Perikanan Kelautan. Sep 1;3(3). 095-106.

Nugraheni W, Marhaeni T, Sucihatiningsih DW. (2012). Peran dan potensi wanita dalam pemenuhan kebutuhan ekonomi keluarga nelayan. Journal of Educational Social Studies. 2012;1(2).104-111.

Laksana YS, Sholih S, Naim M. (2017). Pelatihan tata rias pengantin bagi wanita tuna susila dalam meningkatkan kemandirian usaha. Journal of Nonformal Education and Community Empowerment. Jun 30;1(1):4354.

Minarni EW, Utami DS, Prihatiningsih N. (2017). Pemberdayaan kelompok wanita tani melalui optimalisasi pemanfaatan pekarangan dengan budidaya sayuran organik dataran rendah berbasis kearifan lokal dan berkelanjutan. JPPM (Jurnal Pengabdian dan Pemberdayaan Masyarakat). Dec 14;1(2):147-54.

Rizal M, Setianingsih D, Chandra R. (2016). Faktor-faktor yang Mempengaruhi Wanita Berwirausaha (Studi Kasus di Kota Langsa). Jurnal Manajemen dan Keuangan. Nov 15;5(2):525-34.

Kirana KC, Kusrini K, Purwanto MI. (2018). Analisis Faktor Intensi Kewirausahaan Tenaga Kerja Wanita Purna Gunung Kidul untuk Kemandirian. EKUITAS (Jurnal Ekonomi dan Keuangan). Sep 4;1(3):30324.

Nawawi, H., M Martini. (1996) Penelitian Terapan (Yogyakarta : Gajah Mada University Press,cet . 2).

Prisristiyanti IR. (2012). Persepsi Pegawai Instansi Pemerintah Mengenai Faktor- 
Faktor yang Mempengaruhi Fraud di Sektor Pemerintahan. Accounting Analysis Journal.1(1).1-13

Peraturan Gubernur Jawa Timur Nomor 5 Tahun 2018. (2018). Pedoman Umum Program Jalan Lain Menuju Mandiri Dan Sejahtera Provinsi Jawa Timur Lokasi perkotaan Dinas Pemberdayaan Masyarakat Jawa Timur.

Yoesana U. (2013). Hubungan Antara Motivasi Kerja Dengan Disiplin Kerja Pegawai Di Kantor Kecamatan Muara Jawa Kabupaten Kutai Kartanegara. Journal Pemerintahan Integratif.1:13-27.

Lestari W. (2013). Religiusitas dan persepsi risiko dalam pengambilan keputusan investasi pada perspektif gender. Journal of Business \& Banking (JBB). Nov 1;3(2):189-200.

Carter, S., Shaw, E., Lam, W. and Wilson, F. (2007). Gender, entrepreneurship, and bank lending: The criteria and processes used by bank loan officers in assessing applications. Entrepreneurship Theory and Practice, 31(3), pp.427-444.

Kaluge, L. (2000). Dasar-dasar Administrasi Pendidikan. Surabaya: Unesa Press.

Sudirman D. (2016). Kontribusi dan Motivasi Pekerja Wanita dalam Meningkatkan Ekonomi Keluarga. AL-ULUM: Jurnal Ilmu Sosial dan Humaniora. Apr 8;1(2).175-186.

Chaplin, J.P,. (2008). Kamus Lengkap Psikologi, Alih Bahasa: Kartono Kartini, Raja Grafindo: Jakarta.

Klein KJ, Hodges SD. (2001). Gender differences, motivation, and empathic accuracy: When it pays to understand. Personality and Social Psychology Bulletin. Jun;27(6):72030.

Fredricks JA, Eccles JS. (2005). Family socialization, gender, and sport motivation and involvement. Journal of sport and Exercise Psychology. Mar 1;27(1):3-1. 